\title{
The impact of transportation connectivity on academic achievement of secondary school pupils: a case study of the Donji Miholjac Secondary School, Croatia
}

\section{Utjecaj prometne povezanosti na školski uspjeh srednjoškolaca: primjer Srednje škole Donji Miholjac, Hrvatska}

This study provides an overview of the influence of transportation connectivity as the sole predictor of academic success, using the example of pupils of the Donji Miholjac Secondary School who travel longer distances to school. The study was conducted in April 2016 using the methods of surveying, travel diaries, and pupil interviews. The survey results were compared with information on pupils' academic success for the academic year of 2015/16. The study showed that there was a difference between the success of resident pupils and travelling pupils, in which the effects of other factors were not marginalised. The main issue pertaining to transport and academic success was a lack of alignment between bus schedules and the school's timetable, meaning that travelling pupils are required to spend long amounts of time in transport, which resident pupils are not subjected to, and poorly-planned public transportation routes, in terms of the needs of the travelling pupil, which extended travel time. Though exact data showed differences in academic success, the travelling pupils did not perceive that their daily travels had a significant impact on their academic success.

Key words: etransportation connectivity; travel diary; predictors of academic success; resident pupils; travelling pupils
U radu se problematizira utjecaj prometne povezanosti kao jednoga od prediktora školskoga uspjeha na primjeru učenika putnika Srednje škole Donji Miholjac. Istraživanje je provedeno u travnju 2016. godine metodom anketiranja, dnevnika putovanja i intervjua učenika. Rezultati ankete uspoređeni su s podacima o školskom uspjehu učenika 2015./2016. Istraživanje je pokazalo da postoje razlike između uspjeha stacionarnih učenika i učenika putnika, pri čemu se ne marginalizira utjecaj i ostalih čimbenika. Glavni problemi koji se vezuju uz promet i školski uspjeh su neusklađenost voznoga reda i rasporeda sati, čime učenici putnici imaju velik utrošak vremena u odnosu na stacionirane, te neplaniranje prometnih pravaca javnoga prijevoza prema potrebama učenika putnika, što produljuje putovanje. Iako egzaktni podaci pokazuju razlike u uspjehu, učenici putnici ne smatraju da svakodnevna cirkulacija ima značajniji odraz na njihov školski uspjeh.

Ključne riječi: prometna povezanost; dnevnik putovanja; prediktori školskog uspjeha; stacionirani učenici; učenici-putnici. 


\section{Introduction}

In the contemporary, globalised world, academic accomplishment is considered an important indicator of future success. Academic success (or lack thereof) has an important influence on a pupil's adolescent years, and often becomes the main indicator of personal adaptation and a precondition for success and happiness (Jamil and Khalid, 2016). Here we define academic accomplishment as the successful achievement of set objectives, expressed in the form of grades or descriptive success.

This study examined the influence of transportation connectivity as a predictor of academic success among secondary school pupils. The survey was conducted using the example of pupils at the Donji Miholjac Secondary School. Donji Miholjac is a town in Osijek-Baranja County in the traditional region of Slavonia, Eastern Croatia. The area was chosen because of its border location, and the significant economic and social problems of Eastern Croatia, which have resulted in vast emigration from the region. Under these conditions, Donji Miholjac is trying to attract young families by financing schoolbooks and transportation to school.

The introductory part of the paper defines the concept of predictors and the concept of transport connectivity as one of the predictors of academic success. This is followed by an overview of the relevant literature with emphasis on geographic indicators of success. The second part outlines the methodology employed in the study, and the methods used to process the results. The third part of the paper presents the study results, followed by the discussion and conclusions.

In the literature, various predictors have been noted to have an influence on academic success. Dević (2015) differentiated three groups of predictors of academic success. The first were the individual characteristics of pupils, including intelligence, personality, motivation, and confidence. The second were characteristics of the pupil's environment, including the family's economic status, employment and education of parents, and family structure (siblings). The third consisted of characteristics of the school, teachers and the schooling
Uvod

U suvremenom globaliziranom svijetu školsko postignuće smatra se važnim indikatorom uspješne budućnosti. Školski uspjeh ili neuspjeh ima važan utjecaj na učeničke adolescentske godine te često postaje glavni pokazatelj osobne prilagodbe te preduvjet za uspjeh i sreću (Jamil i Khalid, 2016). Pri tome polazimo od definicije školskoga postignuća kao uspješnoga postizanja zadanih ciljeva koji se iskazuju ocjenama ili opisnim uspjehom.

Ovaj rad bavi se utjecajem prometne povezanosti kao prediktora školskoga uspjeha srednjoškolaca. Anketno istraživanje provedeno je među učenicima Srednje škole Donji Miholjac. Donji Miholjac grad je u Osječko-baranjskoj županiji, u tradicionalnoj regiji Slavoniji, odnosno Istočnoj Hrvatskoj. Područje istraživanja odabrano je kako zbog svojega graničnog položaja tako i zbog ekonomskih i socijalnih problema u ovoj regiji, što rezultira visokim emigracijskim stopama. S druge strane, grad pokušava raznim mjerama (npr. sufinanciranjem prometa i školskih udžbenika) privući mlade obitelji.

Rad je podijeljen na tri dijela. U prvom, uvodnom dijelu, definiraju se pojmovi prediktora školskoga uspjeha te prometna povezanost kao prediktor školskoga uspjeha. Također se daje pregled relevantne literature $s$ naglaskom na geografske prediktore uspjeha. U drugom dijelu objašnjena je metodologija samoga rada. Treći dio donosi rezultate s raspravom i zaključcima.

U dosadašnjoj je literaturi zabilježen utjecaj različitih prediktora na školski uspjeh. Dević (2015) razlikuje tri skupine prediktora školskoga uspjeha. Prvu skupinu čine individualna obilježja učenika koja obuhvaćaju inteligenciju, osobine ličnosti, motivaciju, samouvjerenost. Drugu skupinu čine obilježja učenikove okoline koja obuhvaćaju ekonomsku situaciju obitelji, zaposlenost i obrazovanje roditelja, strukturu obitelji (braća/sestre). Treću skupinu čine obilježja škole, poučavatelja i školskoga procesa, a obuhvaćaju veličinu i vrstu škole, veličinu razreda, osobine učitelja i sl. Drugi autori prediktore dijele na osobne, obiteljske, školske te prediktore šire socijalne okoline. Sličnu podjelu daju i Kuterovac Jagodić i dr. (2013) koji razlikuju osobne, obiteljske i okolinske prediktore. Usprkos 
process, and included the size and type of school, size of class, characteristics of teachers, etc. Other authors have divided predictors into personal, family, school, and broader social environment. A similar division was given by Kuterovac Jagodić et al. (2013). Despite minor differences, these authors agree that it is difficult to clearly determine the strength of the influence of an individual predictor on academic success. Furthermore, most authors agree that examining the predictors of academic success is important for many reasons. Understanding the predictors allows us to contribute, often with minor adjustments to the system or elimination of certain conditions, to significant increases in pupil accomplishment.

There are few studies dealing with a theoretical approach to the predictors. Some of the notable studies are those by Babarović et al. (2009; 2010), who gave an overview of the cognitive factors, environmental factors, and particularly the socioeconomic status of the family, properties of the teaching process, and school properties as the most commonly used predictors. The review paper by Jamil and Khalida (2016) gave a significant contribution to the overview of the work to date on the influence of individual personal predictors. A broad spectrum of predictors and their influence on academic accomplishment amongst Turkish secondary school pupils was examined by Yesilyurt and Say (2016), Saw (2016), and Raychaudhuri et al. (2010).

Papers addressing individual indicators can be divided into several categories, depending on the predictor. Gender as a predictor of academic success, at all educational levels, has been studied by Zhang and Chen (2013) and Autor et al. (2016), for example. The second group includes papers on different forms of behaviour relating to academic success. Păişi Lăzărescu (2014) gave an overview of psychological factors of academic success. Dautović (1999) and Nelson et al. (2004) gave overviews of the relationship between emotional issues in children and youth in relation to their academic success. Gyansah et al. (2015) examined the influence of delinquency and drug abuse on academic success. Delinquency was also analysed by Maguin and Loeber (1996) and Masten et al. (2005). The third group određenim razlikama u podjelama svim je autorima zajedničko slaganje oko činjenice da je teško jasno odrediti jačinu utjecaja pojedinih prediktora na školski uspjeh. Autori se također slažu da je proučavanje prediktora na školski uspjeh važno s više aspekata. Proučavanje prediktora omogućuje nam $\mathrm{da}$, često uz manje preinake sustava ili uklanjanje određenih stanja, pridonesemo znatnom povećanju učeničkih postignuća.

Od brojnih autora koji se bave utjecajem različitih faktora ili prediktora na školski uspjeh mi ćemo ovdje spomenuti samo neke. Pritom valja reći da većina autora u svojim radovima analizira utjecaj pojedinih prediktora, dok je broj radova koji se bave teorijskim pregledom prediktora znatno manji. Među njima se izdvajaju radovi Babarovića i dr. (2009; 2010), koji daju prikaz kognitivnih i okolišnih čimbenika, a posebice socio-ekonomskoga statusa obitelji, obilježja nastavnoga procesa te obilježja škole kao najčešće korištenih prediktora. Pregledni rad Jamil i Khalid (2016) daje važan prilog pregledu dosadašnjih radova o utjecaju pojedinih osobnih prediktora. Širi spektar prediktora i njihov utjecaj na školska postignuća turskih srednjoškolaca analizira se u Yesilyurt i Say (2016), Saw (2016) i Raychaudhuri i dr. (2010).

Radove koji se bave pojedinim prediktorima možemo podijeliti u nekoliko skupina ovisno o istraživanom prediktoru. U prvu skupinu radova ubrajamo radove koji se bave spolom kao prediktorom školskoga uspjeha na svim razinama obrazovanja (npr. Zhang i Chen, 2013; Autor i dr., 2016). U drugu skupinu radova možemo ubrojiti radove koji se bave utjecajem različitih oblika ponašanja na školski uspjeh. Tako se u P. Lăzărescu (2014) daje pregled psiholoških čimbenika na školski uspjeh proučavanjem utjecaja psiholoških karakteristika kao što su obazrivost, razina samopouzdanja i samopotvrđivanja na školski uspjeh, dok se u Dautović (1999) prikazuje odnos emocionalnih problema djece i mladeži i školskoga uspjeha. Sličnim temama bave se i Nelson i dr. (2004). Gyansah i dr. (2015) bave se utjecajem delikvencije i zloporabe droga na školski uspjeh ističući značajnu korelaciju između zloporabe droga i alkohola i niske razine školskoga uspjeha. Delikvencijom i školskim uspjehom bave se i Maguin i Loeber (1996) te Masten
T. Pleić

M. Jakovčić

Impact of transportation connectivity on the academic

achievement of secondary school pupils: case study of the Donji Miholjac Secondary School, Croatia

Utjecaj prometne povezanosti na školski uspjeh srednjoškolaca: primjer Srednje škole Donji

Miholjac, Hrvatska 
GEOGRAFSKI

GLASNIK

79/2, 87-108 (2017.) includes parental behaviour as a predictor of academic success (e.g. Sremić and Rijavec, 2010; Tang and Davis-Kean, 2015; Alameda-Lawson, 2014; Kramer, 2012; Macuka and Burić, 2015; Kamaruddin et al., 2009). The fourth group includes papers analysing the predictor of socioeconomic status of the family. Some authors classify this predictor into the group of family predictors, while others, e.g. Macuka and Burić (2015), classify it as an environmental predictor. The influence of socioeconomic status has also been analysed by Friedman-Krauss and Raver (2015), Kuterovac Jagodić et al. (2013), Zhijun et al. (2016), and Gregurović and Kuti (2009). The influence of family size was examined by Downey (1995).

There are fewer papers that address the influence of geographic predictors. Kuterovac Jagodić et al. (2013) emphasised the correlation between school location and academic success. However, the authors classified school location as schools in urban vs. rural areas, without consideration for the issues of transportation connection and accessibility of certain locations. Similar topics were addressed by Burušić et al. (2012) and Owoeye and Yara (2011). School location (in the sense of urban vs. rural) was also analysed by Barbarović et al. (2010). And while there are few papers dealing with geographic predictors, there are even fewer studies focusing on the influence of transport connectivity and accessibility of schools on academic success. Most papers examine accessibility and the use of individual types of telecommunications, such as Internet, in relation to academic success. For example, Maras and Rodek (2012) analysed the influence of Internet access and the possession of a personal computer in relation to academic success. The number of geographic papers is even fewer, and one of the rare authors in this field is S. Gašparović (2014a; 2014b). In his doctoral dissertation, Gašparović studied the impacts of transport marginalisation on the daily life of the secondary school population in the City of Zagreb, where transport marginalisation was defined as "the inability to travel when and where one wants without difficulty" or as a "situation in which people experience, for different reasons, a deficiency of transport opportunities, which restricts their mobility and access to goods, services, and interac- i dr. (2005). U treću skupinu radova možemo ubrojiti radove u kojima je prediktor školskoga uspjeha roditeljsko ponašanje (npr. Sremić i Rijavec, 2010; Tang i Davis-Kean, 2015; Alameda-Lawson, 2014; Kramer, 2012; Macuka i Burić, 2015; Kamaruddin i dr., 2009). Širom skupinom okoline kao prediktora bave se Kamaruddin i dr. (2009). U četvrtu skupinu možemo ubrojiti radove u kojima je prediktor socioekonomski status obitelji. Pojedini autori ovaj prediktor ubrajaju u skupinu obiteljskih prediktora, dok ih neki poput Macuka i Burić (2015) ubrajaju u skupinu okolišnih prediktora. Utjecajem socioekonomskoga statusa bave i radovi Friedman-Krauss i Raver (2015), Kuterovac Jagodić i dr. (2013), Zhijun i dr. (2016), Gregurović i Kuti (2009). Utjecaj veličine obitelji na školski uspjeh obrađuje Downey (1995).

Radova koji se bave geografskim prediktorima znatno je manje. Kuterovac Jagodić i dr. (2013) ističu povezanost lokacije škole i školskoga uspjeha. Međutim, autori polaze od lokacije škola u smislu smještaja u urbanim ili ruralnim sredinama, a ne od problema prometne povezanosti i dostupnosti pojedinih lokacija. Sličnim temama bave se Burušić i dr. (2012) te Owoeye i Yara (2011). Lokaciju škola (u smislu smještaja u ruralnim ili urbanim područjima) spominju i Barbarović i dr. (2010), pri čemu lokaciju škole kao obilježje škole dovode u vezu s veličinom razreda i škole, odnosno brojem učenika te utjecajem na školski uspjeh. I dok je broj radova koji se bave geografskim prediktorima općenito malen, još je manji broj radova koji se bave utjecajem prometne povezanosti i dostupnosti na uspjeh učenja. Najbrojniji su radovi koji se bave dostupnošću i korištenjem pojedinih vrsta telekomunikacijskoga prometa, primjerice interneta. Tako Maras i Rodek (2012) analiziraju utjecaj dostupnosti interneta i posjedovanja osobnoga računala na školski uspjeh. Broj geografskih radova i njihovih autora još je manji, a među rijetkima se ističe $\mathrm{S}$. Gašparović (2014a; 2014b). U svojoj doktorskoj disertaciji Gašparović proučava utjecaj prometne marginaliziranosti na svakodnevni život srednjoškolske populacije grada Zagreba. Prometnu marginalizaciju definira kao "nemogućnost putovanja kada i kamo se želi bez poteškoća” ili kao „situaciju u kojoj ljudi iz određenih razloga doživljavaju uskraćivanje korištenja prometnih mogućnosti što 
tions" and examined the influence of such transport marginalisation on academic activities (Gašparović, 2014a, 31.). In so doing, he also examined the influence of transport connectivity and traffic problems on academic success. His results indicated a significant connection between the distance from home to school, and the length of travel to school with academic success (Pearson's correlation coefficient $r=-0.139$ ) (Gašparović, 2014a; 2014b). He concluded that pupils who take public transport to school had somewhat lower academic success than pupils who did not. Travel time to school had a negative value in the regression analysis, indicating that pupils who spent a longer time travelling to school had lower academic success. The same topic was addressed by Gašparović and Jakovčić (2014). In that study, transport marginalisation was defined as a situation in which people, for different reasons, experienced a deficiency of transport opportunities, which restricted their mobility and access to goods, services, and interactions. Reasons for this deficiency can vary, and for this research we used the factor of age. According to Croatian law, people under age of 18 are not permitted to drive a car, which can have a large effect on transportation connectivity for the secondary school population.

To better understand the issues of transport connectivity and accessibility as a predictor of academic success, it is necessary to define the concepts of transport mobility, transport connectivity, and transport accessibility. Transport is an activity that represents the movement of people, goods and energy, and the transport of information from one place to another (Black, 2003). The purpose of transport is the movement from one place to another to satisfy fundamental life needs, and in this study, it pertains to the function of education.

Transport mobility, physical or virtual, can be defined as the possibility and need for the movement of people, particularly as physical movement Gašparović (2014a; 2014b). Two basic groups of factors affect personal mobility: social and physical. In the present study the emphasis is placed on physical factors, which include the existence of certain forms of transport and their appropriate schedule. Transport accessibility means the ability or ease of accessing the transport system, ograničava njihovu mobilnost i pristup dobrima, uslugama i interakcijama" te proučava utjecaj prometne marginaliziranosti kao takve na školske aktivnosti (Gašparović, 2014a, 31). Pri tome istražuje i utjecaj prometne povezanosti i problema u prometu na školski uspjeh. Ti rezultati upućuju na značajnu povezanost između udaljenosti mjesta stanovanja od škole, duljine putovanja i školskoga uspjeha (Pearsonov koeficijent korelacije $\mathrm{r}=-0,139)$ (Gašparović, 2014a; 2014b). Također zaključuje da učenici koji putuju u školu javnim gradskim prijevozom imaju i nešto lošiji školski uspjeh od ostalih učenika. Vrijeme putovanja do škole i u regresijskoj analizi ima negativan $\beta$, što upućuje na to da pojedinci koji više vremena provode u putovanju do škole imaju i nešto lošiji školski uspjeh. Istom tematikom bavi se i rad Gašparovića i Jakovčić (2014) koji analizira utjecaj prometne marginaliziranosti na svakodnevni život srednjoškolske populacije Grada Zagreba. Pri tome prometnu marginaliziranost definiraju kao situaciju u kojoj ljudi iz određenih razloga doživljavaju uskraćivanje korištenja prometnih mogućnosti što ograničava njihovu mobilnost i pristup dobrima, uslugama i interakcijama. Razlozi ograničavanja mobilnosti mogu biti raznovrsni, a nama je u ovom istraživanju najzanimljiviji čimbenik dob učenika. Naime, prema hrvatskim zakonima osobe mlađe od 18 godina ne smiju samostalno upravljati osobnim vozilom, što znatno utječe na prometnu povezanost srednjoškolske populacije.

Za bolje razumijevanje proučavane problematike prometne dostupnosti i povezanosti kao prediktora školskoga uspjeha potrebno je definirati pojmove prometne mobilnosti, prometne povezanosti i prometne dostupnosti. Promet je djelatnost prijevoza ljudi, dobara i energije te prijenosa informacija $\mathrm{s}$ jednoga mjesta na drugo (Black, 2003). Njegova je svrha prijevoz s jednoga mjesta na drugo radi zadovoljavanja osnovnih životnih potreba, u našem istraživanju to je obrazovanje.

Prometnu mobilnost, fizičku ili virtualnu, možemo definirati kao mogućnost i potrebu za kretanjem ljudi, odnosno kao fizičko kretanje Gašparović (2014a; 2014b). Na mobilnost pojedinca utječu dvije osnovne skupine čimbenika: socijalne i fizičke. U našem istraživanju naglasak prvenstveno stavljamo na fizičke čimbenike koji između osta-
T. Pleić M. Jakovčić

Impact of transportation connectivity on the academic achievement of secondary school pupils: case study of the Donji Miholjac Secondary School, Croatia

Utjecaj prometne povezanosti na školski uspjeh srednjoškolaca: primjer Srednje škole Donji

Miholjac, Hrvatska 
GEOGRAFSKI

GLASNIK

79/2, 87-108 (2017.) and meeting fundamental life needs and functions through the use of the transport system (Gašparović, 2014a; Halden et al., 2005). Accessibility can also be defined as the degree of ability by which we can access activities and functions within the framework of acceptable costs, within a reasonable time, and with tolerable ease (Gašparović, 2014a). Accessibility is the connection among individual transport hubs (function) within the transport network. Transport connectivity indicates the degree of connection between individual hubs (functions, or, in the present study, the function of education) within a certain transport network. Accessibility of means of transport is of the utmost importance to achieving life functions. In general, the greater the accessibility and higher the degree of connectivity, i.e. the access to various functions as the function of education, is desirable. If this mobility or accessibility is hindered, this will result in a limitation of the opportunities to fulfil one's needs, and therefore will lead to the appearance of transport marginalisation (Gašparović, 2016; Hoyle and Knowles, 1998).

The main objective of the research was to determine how transport connectivity, as a geographic predictor, affected academic success. The starting hypothesis is that transport connectivity is an objective geographic predictor of academic success. The second hypothesis set is that the degree of transport connectivity influences academic success - with the assumption that there is a positive correlation of connectivity for travelling pupils, i.e. that poor transport connectivity will have a negative impact on academic success.

\section{Methods}

In order to test the set hypotheses, surveys and travel diaries were used as a primary source, accompanied by comparisons of grade averages of pupils, with differentiation into groups of resident and travelling pupils, and with the overall population of pupils in that generation and the type of school programme.

Having in mind contradictory opinions on how the questionnaires should be formulated in loga podrazumijevaju postojanje pojedinih oblika prometa i njihov prikladan raspored. Prometna dostupnost označava mogućnost ili lakoću pristupa prometnom sustavu te zadovoljenje osnovnih životnih potreba i funkcija korištenjem prometnoga sustava (Gašparović, 2014a; Halden i dr., 2005). Dostupnost također možemo definirati i kao stupanj mogućnosti kojom možemo pristupati životnim aktivnostima i funkcijama u okviru prihvatljivih troškova, u razumnom vremenu i s podnošljivom lakoćom (Gašparović, 2014a). Dostupnost označava povezanost pojedinih prometnih čvorova (funkcija) unutar prometne mreže. Prometna povezanost označava stupanj povezanosti pojedinih čvorova (funkcija ili u našem istraživanom slučaju funkcije obrazovanja) unutar određene prometne mreže. Dostupnost prijevoznih sredstava izrazito nam je važna pri ostvarivanju životnih funkcija. U osnovi naime vrijedi da što je dostupnost bolja i stupanj povezanosti veći, pristup različitim funkcijama bit će lakši, odnosno bolji. Ako je ta mobilnost ili dostupnost otežana doći će do ograničene mogućnosti zadovoljavanja potreba a posljedično i do pojave prometne marginaliziranosti (Gašparović, 2016; Hoyle i Knowles, 1998).

Osnovni je cilj istraživanja utvrditi kako prometna povezanost kao geografski prediktor utječe na školski uspjeh. Dvije su osnovne hipoteze: (1) prometna povezanost objektivni je prediktor školskoga uspjeha i (2) stupanj prometne povezanosti utječe na školski uspjeh učenika putnika, pri čemu pretpostavljamo pozitivnu korelaciju povezanosti, tj. lošija prometna povezanost imat će negativan utjecaj na školski uspjeh.

\section{Metode}

Kako bi se ispitale istraživačke hipoteze, kao odgovarajuće metode odabrane su anketa (klasično anketno ispitivanje te dnevnik putovanja s pripadajućim intervjuom) i eksplicitne usporedbe prosjeka učenika s razvidnom diferencijacijom na stacionirane učenike i učenike putnike te s cjelokupnom populacijom učenika u pojedinoj generaciji i vrsti programa (trogodišnja, odnosno četverogodišnja strukovna škola te gimnazija). 
researching transport issues (Moser and Kalton, 1979, as cited in Richardson et al., 1995), a questionnaire with 20 questions was drawn up. The first group of questions collected personal data, while the second group of questions was concerned the information, opinions, and perceptions of transport and transport connectivity. For this paper, representative questions were selected. The survey included the complete population of travelling pupils at the Donji Miholjac Secondary School. Surveying was conducted in April 2016 at the school, with the prior consent of parents for minor pupils and the consent of pupils of legal age, and with the cooperation of the school's professional services. A total of 245 travelling pupils were questioned, $92.1 \%$ of all travelling pupils attending the Donji Miholjac Secondary School, and $63.6 \%$ of the total number of pupils at this school. After reviewing the questionnaires, it was confirmed that 224 pupils (91.4\%) had completed the questionnaires completely and validly, in accordance with the instructions, and their responses were considered for further use in this study. The survey results were analysed using the IBM SPSS Statistics 23 program.

The second method used in this study was the daily travel diary. Two pupils from the same class and with the same schedule, but from different places of residence (one female travelling pupil and one male resident pupil), were asked to record their travels over two weeks (one week in the morning shift and one week in the afternoon shift). The travelling pupil was asked to write down the precise start and end times of the following: travel from home to the bus station and back; the start and end of the ride to school and back; and arrival from the bus station to the school and back. On the other hand, the resident pupil was only required to record how long it took to get to school and back home. Though this was a small sample, the travel diary served as an exemplary model for differentiating time spent travelling from home to school and back. The same pupils were interviewed following the keeping of the travel diary, and asked a set of questions that gave more complex answers than the questions posed in the questionnaire. Travel diaries are an established means used to study patterns of traveller behaviour, and for planning transport (Axhausen et al., 2002).
Prva anketna metoda klasično je anketno ispitivanje s unaprijed pripremljenim upitnicima. Postoje oprečna mišljenja o tome kako pitanja trebaju biti formulirana prilikom istraživanja prometa te pojava i procesa vezanih uz promet, odnosno trebaju li ona ispitivati isključivo slaganje ili neslaganje s tvrdnjama (Moser i Kalton, 1979, prema Richardson i dr., 1995) ili trebaju uključivati mišljenja. U ovom su anketiranju korištena oba tipa pitanja. Upitnik se sastojao od 20 pitanja. Prvom skupinom pitanja prikupljeni su podaci o dobi, spolu i mjestu stanovanja ispitanih, dok su drugom skupinom pitanja dobiveni podaci, stajališta i percepcija prometa i prometne povezanosti. $\mathrm{Za}$ ovo istraživanje izabrana su reprezentativna pitanja. Anketa je obuhvatila svu populaciju učenika putnika Srednje škole Donji Miholjac. Anketiranje je provedeno u travnju 2016. godine u školi uz prethodne privole roditelja za maloljetne učenike, odnosno vlastite privole za punoljetne učenike, uz suradnju stručne službe. Ukupno je ispitano 245 učenika putnika, tj. 92,1 \% svih učenika putnika u Srednjoj školi Donji Miholjac, odnosno $63,6 \%$ svih učenika ove srednje škole. Nakon pregleda upitnika 224 ispitanika $(91,4 \%)$ su u potpunosti i valjano, sukladno uputama, ispunila upitnike te su njihovi odgovori uzeti u obzir. Rezultati ankete analizirani su u programu IBM SPSS Statistics 23.

Druga metoda korištena u ovom istraživanju jest dnevnik putovanja. Dvoje učenika istoga razreda te istoga rasporeda, ali različita mjesta stanovanja (učenica putnica te stacionirani učenik) tijekom dva tjedna (u jednom tjednu jutarnja smjena, u drugom popodnevna) ispunjavali su svoj obrazac putovanja prateći točno vrijeme početka i kraja kretanja od doma do autobusne stanice i natrag, početka i kraja vožnje do škole i natrag, dolaska od autobusne stanice do škole i natrag (učenica putnica), odnosno stacionirani učenik vrijeme početka kretanja od doma do škole i natrag. Iako na malom uzorku, dnevnik putovanja poslužio je kao egzemplarni model razlikovanja utrošenoga vremena za dolazak iz mjesta stanovanja u mjesto školovanja i obratno. Isti učenici intervjuirani su nakon vođenja dnevnika putovanja nizom pitanja kojim su davali kompleksnije odgovore nego na pitanja postavljena u upitniku. Dnevnici putovanja jedan su od načina proučavanja obrazaca
Impact of transportation connectivity on the academic achievement of secondary school pupils: case study of the Donji Miholjac Secondary School, Croatia

Utjecaj prometne povezanosti na školski uspjeh srednjoškolaca: primjer Srednje škole Donji

Miholjac, Hrvatska 
GEOGRAFSKI

GLASNIK

79/2, 87-108 (2017.)
The third method used in the research was a self-evaluation. Pupils were asked to estimate the impact of the time spent daily going to and from school in relation to their respective levels of school achievement. Their answers were then compared with their exact level of school achievement, obtained from school administration. School achievements were analysed in regard to the type of school, school year, and place of residence (travelling pupils vs. resident pupils). A distinction was made between the three-year vocational programme, four-year vocational programme, and gymnasium programme, as there were differences in the profiles of pupils enrolled in these different programmes, which were most evident in academic success level upon enrolment in secondary school. Academic success in primary school is one of the main factors for selecting pupils for enrolment in a given secondary school programme, which leaves repercussions on "the possibilities for further schooling and selection of a profession" (Macuka and Burić, 2015, p. 417). The average of a particular year and education profile, with respect to the duration of school, is marked with the 100 index, while the average of travelling pupils and resident pupils is expressed as the ratio of the average of travelling pupils or resident pupils to the average of the specific year and educational profile. General academic success was provided by the school administration, without any reference to pupils' personal information.

\section{Results}

Of the surveyed travelling pupils, $53.6 \%$ were male and $46.4 \%$ were female. The age structure of the respondents is visible in Tab. 1 . The gravity reach of the function of secondary school education was covered by a circle of roughly 40 kilometres. The travelling pupils from city neighbourhoods (5.6\%) should in this case be differentiated from those from rural settlements and the immediate area (94.4\%).

Once the gravitational area of the Donji Miholjec Secondary School was determined as a function of the place of residence of the travelling pupils, it was necessary to determine the means by which travelling pupils travelled to school. The distribution of putničkoga ponašanja, ali i planiranja prometa $(\mathrm{Ax}-$ hausen i dr., 2002), pri čemu je planiranje prometa, odnosno usklađenost voznoga reda sa školskim rasporedom učenika jedno od temeljnih pitanja kada se govori o učenicima putnicima.

Treća upotrijebljena metoda jest samoprocjena kojoj je cilj utvrditi u kojoj mjeri su učenici objektivno procijenili utjecaj svakodnevnoga prometa na školski uspjeh, pri čemu su njihovi odgovori uspoređeni s općim školskim uspjehom koji su postigli. Podaci o općem školskom uspjehu analizirani su s obzirom na školsko godište, vrstu srednje škole te s obzirom na mjesto stanovanja učenika (učenik putnik, odnosno stacionirani učenik). Učinjena je distinkcija između učenika trogodišnje, četverogodišnje strukovne škole i gimnazije jer postoje razlike između profila učenika koji pohađaju određena usmjerenja, a koja je najočitija u školskom uspjehu s kojim dolaze u srednju školu. Školski uspjeh u osnovnoj školi jedan je od čimbenika koji izdvaja učenike za upis u određenu srednju školu, ostavljajući posljedice na „mogućnost daljnjeg školovanja i odabir zanimanja" (Macuka i Burić, 2015, 417). Prosjek godišta i obrazovnoga profila s obzirom na trajanje školovanja označen je indeksom 100, dok je prosjek učenika putnika i stacioniranih učenika izražen kao omjer prosjeka učenika putnika odnosno stacioniranih učenika i prosjeka određenoga godišta i obrazovnoga profila. Opći školski uspjeh ustupila je uprava škole, uz izostavljanje bilo kakvih osobnih podataka učenika.

\section{Rezultati}

Od ukupnoga broja anketiranih 53,6 \% bili su mladići, a 46,4 \% djevojke. Dobna struktura ispitanih vidljiva je u Tab. 1. Gravitacijski doseg funkcije srednjeg školstva obuhvaćen je krugom od oko 40 kilometara. Učenici-putnici iz gradskog naselja čine 5,6\% ispitanih dok je iz ruralnih naselja i inicijalnih središta njih 94,4 \% ispitanih.

Nakon što je utvrđeno gravitacijsko područje funkcije srednjega školstva Donjeg Miholjca samim mjestom prebivanja učenika putnika, potrebno je odrediti sredstvo dolaska učenika putnika u mjesto školovanja. Od ukupno 224 ispitana učenika putnika svega 2 učenice, obje starije od 18 godina, u školu 
Tab. 1 Surveyed pupils by age

Tab. 1. Anketirani prema navršenim godinama

\begin{tabular}{|c|c|c|}
\hline Age / Dob & Number of pupils / Broj učenika & Percentage (\%) / Udio (\%) \\
\hline 14 & 1 & 0.4 \\
\hline 15 & 44 & 19.6 \\
\hline 16 & 62 & 27.7 \\
\hline 17 & 59 & 26.3 \\
\hline 18 & 48 & 21.4 \\
\hline 19 & 8 & 3.6 \\
\hline 20 & 2 & 0.9 \\
\hline Total / Ukupno & 224 & 100 \\
\hline
\end{tabular}

Source: Survey (Pleić and Jakovčić, 2016)

Izvor: Anketa (Pleić i Jakovčić, 2016)

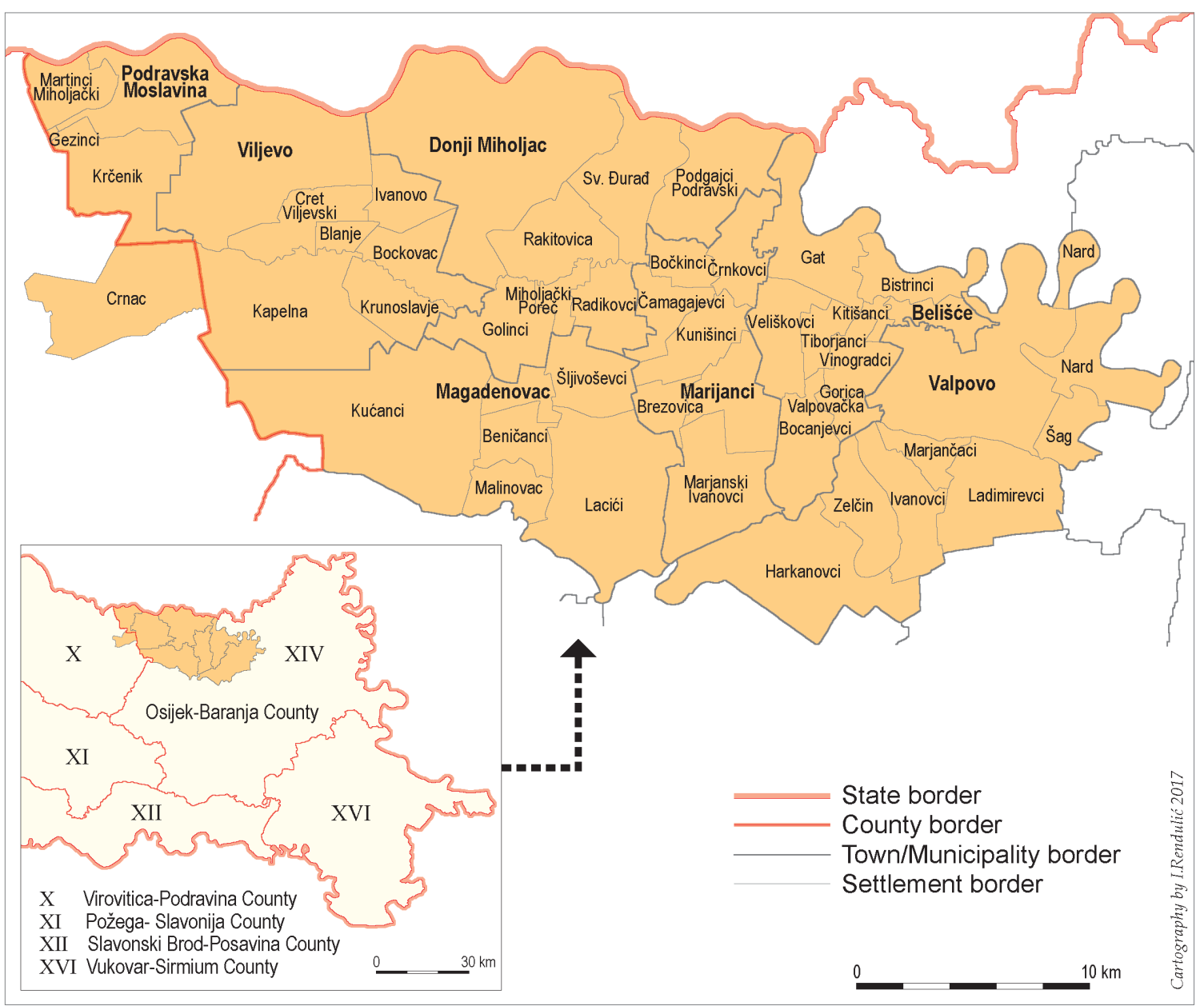

Fig.1 Gravitation area of Donji Miholjac Secondary School

SI. 1. Gravitaciisko područje srednje škole Donji Miholac

Source: Survey (Pleić and Jakovčić, 2016)

Izvor: Anketa (Pleić i Jakovčić, 2016) 
GEOGRAFSKI

GLASNIK

79/2, 87-108 (2017.) answers showed that only 2 out of 224 interviewees, both over 18 years of age, travelled to school by car, while all the others used public transportation.

In the further analysis, only the pupils who went to school via bus were included, since they were directly dependent on the (bus) schedule in order to get to school and return home. These pupils were asked a series of questions relating to transport connectivity, their perceptions regarding transport connectivity, and their perceptions of the influence of transport connectivity and their daily travels in relation to their academic success.

Considering that the pupils lived in different settlements, the mean travel time and the total travel time from home to school and back was assessed. Results are presented in table 2. dolaze automobilom, dok svi ostali u školu dolaze autobusom.

U daljnjim rezultatima koncentrirat ćemo se na ispitanike koji do škole dolaze autobusom jer oni izravno ovise o redu vožnje kako bi došli do škole i vratili se natrag u mjesto prebivanja. Postavljen im je niz pitanja vezanih uz prometnu povezanost, doživljaj prometne povezanosti te percepciju utjecaja prometne povezanosti i svakodnevne vožnje na školski uspjeh.

S obzirom na to da ispitanici žive u različitim naseljima, ispitanici su prvo procjenjivali prosječno trajanje vožnje od stanice u mjestu prebivališta do stanice u mjestu školovanja, odnosno iz mjesta školovanja do mjesta prebivanja. Rezultati su izneseni u Tab. 2.

Tab. 2 The total mean travel time to school

Tab. 2. Prosječno ukupno vrijeme putovanja do škole

\begin{tabular}{|c|c|}
\hline $\begin{array}{c}\text { Mean total travel time (min) } \\
\text { / Prosječno ukupno vrijeme putovanja (min) }\end{array}$ & $\begin{array}{c}\text { Percentage of pupils (\%) } \\
\text { / Udio učenika (\%) }\end{array}$ \\
\hline$<10$ & 9.9 \\
\hline $11-15$ & 22.5 \\
\hline $16-20$ & 15.8 \\
\hline $21-30$ & 25.7 \\
\hline $30-45$ & 19.9 \\
\hline$>45$ & 6.3 \\
\hline Total / Ukupno & 100 \\
\hline
\end{tabular}

Source: Survey (Pleić and Jakovčić, 2016)

Izvor: Anketa (Pleić i Jakovčić, 2016)

The next two questions involved the alignment of the bus schedule with the school's timetable, and the relevant indicator was the time the pupils had at their disposal between the arrival of the bus to Donji Miholjac and the beginning of school, and the time available between the end of school and the departure of the bus from the stop or station for the ride home. In this specific case, pupils were asked to use a day with seven classes as the reference day. The results are shown in Table 3. The average wait time in the morning is about 19 minutes, while the average in the afternoon is about 11 minutes.
Sljedeća dva pitanja vezana su uz usklađenost voznoga reda sa školskim rasporedom, a kao relevantan pokazatelj poslužilo je vrijeme koje učenici imaju na raspolaganju između dolaska autobusa u Donji Miholjac i prvoga školskog sata, odnosno vrijeme koje učenici imaju na raspolaganju nakon zadnjega školskog sata i dolaska autobusa na stanicu, odnosno kolodvor na povratku prema kući. U konkretnom slučaju ispitanici su zamoljeni da kao referentni školski raspored uzmu onaj od sedam školskih sati. Rezultati su prikazani u Tab. 3. Prosječno vrijeme čekanja u prvom slučaju iznosi oko 19 minuta, a u potonjem oko 11 minuta. 
Tab. 3 The time pupils have available between the arrival of the bus and the beginning of school, and between the end of school and the departure of the bus for the ride home

Tab. 3. Vrijeme koje učenici imaju na raspolaganju između dolaska autobusa u mjesto školovanja i početka prvog školskog sata te kraja zadnjeg školskog sata i dolaska autobusa za polazak kući

\begin{tabular}{|c|c|c|}
\hline $\begin{array}{c}\text { Waiting time (min) } \\
\text { /Vrijeme čekanja (min) }\end{array}$ & $\begin{array}{c}\text { Percentage (\%) of respondents in } \\
\text { relation to wait time until beginning } \\
\text { of the school } \\
\text { / Udio ispitanih (\%) sobzirom na vri- } \\
\text { jeme čekanja do prog školskog sata }\end{array}$ & $\begin{array}{c}\text { Percentage (\%) of respondents in } \\
\text { relation to wait time after the 7th } \\
\text { class period } \\
\text { / Udio ispitanih (\%) sobzirom na } \\
\text { vrijeme čekanja nakon sedmog } \\
\text { školskog sata }\end{array}$ \\
\hline$\leq 10$ & 51.1 & 67.9 \\
\hline $10-15$ & 10.0 & 14.5 \\
\hline $15-20$ & 4.1 & 5.4 \\
\hline $20-30$ & 5.0 & 6.3 \\
\hline $30-45$ & 15.8 & 2.3 \\
\hline$\geq 45$ & 14.0 & 3.6 \\
\hline Total / Ukupno & 100 & 100 \\
\hline
\end{tabular}

Source: Survey (Pleić and Jakovčić, 2016)

Izvor: Anketa (Pleić i Jakovčić, 2016)

The pupils were then asked to assess four statements on a scale of 1 to 5 (in which 1 = strongly disagree with the statement, and $5=$ strongly agree with the statement). Those pupils without an opinion were given the opportunity to write the number 0 next to the question, though there were no such cases. Questions and answers are presented in Figure 2.
T. Pleić

M. Jakovčić

Impact of transportation connectivity on the academic achievement of secondary school pupils: case study of the Donji Miholjac Secondary School, Croatia

Utjecaj prometne povezanosti na školski uspjeh srednjoškolaca: primjer Srednje škole Donji Miholjac, Hrvatska

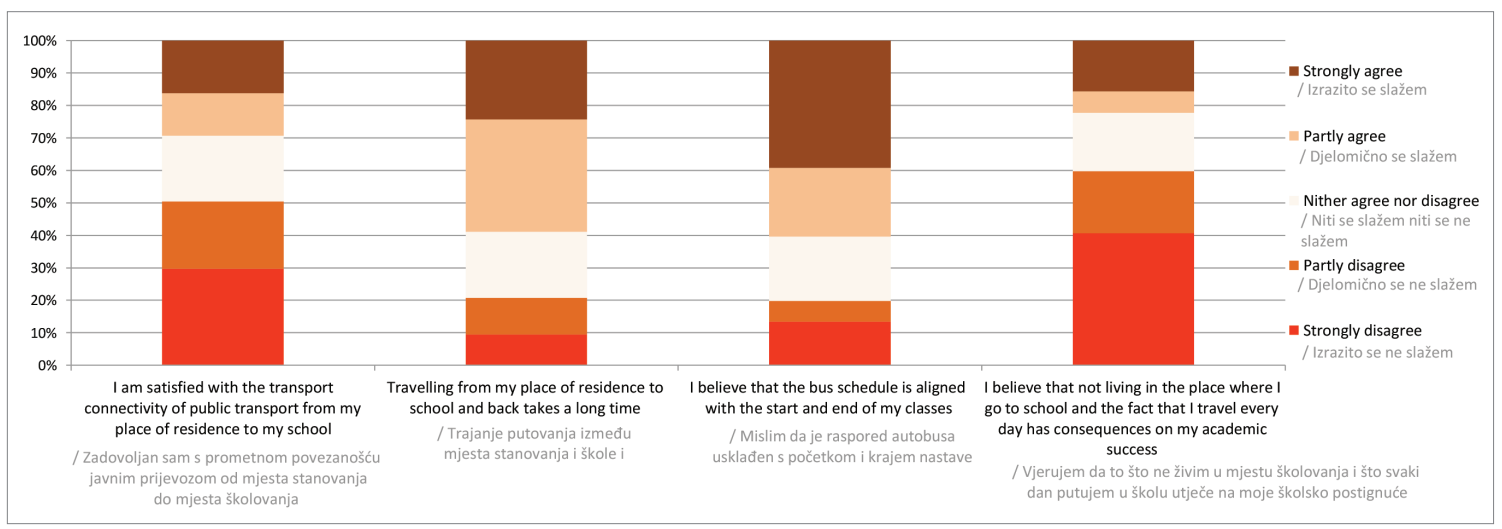

Fig. 2 Pupils' opinions on the quality of transport connection, length of a journey, alignment of the bus schedule, and impact of transportation on student achievement

SI. 2. Stavovi učenika o kvaliteti prometne povezanosti, trajanju putovanja, usklađenosti voznog reda i rasporeda te utjecaju na školsko postignuće

Source: Survey (Pleić and Jakovčić, 2016)

Izvor: Anketa (Pleić i Jakovčić, 2016) 
GEOGRAFSKI

GLASNIK

79/2, 87-108 (2017.)
The claim "I believe that not living in the place where I go to school and the fact that I travel every day has consequences on my academic success", was intended to obtain a self-assessment of pupil success. Although $40.6 \%$ of pupils strongly disagreed, $42.8 \%$ of those travelling for more than 45 minutes responded that the length of their travels affected their academic success. Among those travelling for longer than 30 minutes, $24.1 \%$ responded that they strongly agreed. With regard to educational profile, gymnasium pupils responded $16.2 \%$ (1), $16.2 \%$ (2), 9.3\% (3), $7.0 \%$ (4) and $51.1 \%$ (5), pupils of the three-year programme responded 55\% (1), $15.2 \%$ (2), $8.5 \%$ (3), 5.1\% (4) and $7.6 \%(5)$, while pupils of the four-year vocational programmes responded $24.3 \%$ (1), 23\% (2), 35.1 (3), $12.2 \%$ (4) and 5\% (5).

Pupils were asked to assess the quality of public transport service on a scale of 1 to 5 . The average score obtained was 3.61 .

In addition to the anonymous survey responses, for the purposes of this study, two travel diaries were kept. The first diary was kept by a female travelling pupil from the settlement of Viljevo, 9.5 $\mathrm{km}$ away from Donji Miholjac. The pupil lives 200 metres from the bus station and takes the bus to school and home every day. Since the pupil lives less than 400 metres from the public bus stop, as the accepted distance, she cannot be considered to be a transport-marginalised person. She kept a daily travel diary with the exact times of the start and finish of all trips to and from school (in the morning shift from April $4^{\text {th }}$ to $8^{\text {th }}, 2016$, and in the afternoon shift from April $11^{\text {th }}$ to $15^{\text {th }}, 2016$ ). The same travel diary was kept by a male resident pupil, who lives 700 metres (direct distance) from the school. The pupils are in the same class with the same class timetable. Results are represented in tables 4 to 7 .

In the interview that followed, the female travelling pupil stated: “... in comparison to going by car, it's two or three times longer, because we do not go directly to Miholjac, but collect people in the surrounding villages." She also stated that her main problem during the morning school weeks was that she felt she that was sleeping much less than the other pupils in her class, because by taking the long route, she needed to leave earlier; while
$\mathrm{Na}$ tvrdnju Smatram da to što ne živim u mjestu školovanja te što putujem u školu svakodnevno ima posljedice na moj školski uspjeh pri čemu se tražila samoprocjena učenikova uspjeha, distribucija je bila sljedeća: izrazito neslaganje s tvrdnjom izrazilo je 40,6 \% ispitanih, djelomično neslaganje izrazilo je 19,2\%, indiferentan stav izrazilo je 17,9\%, djelomično slaganje s tvrdnjom izrazilo je 6,7 \%, a izrazito slaganje njih 15,6 \%. Međutim, čak $42,8 \%$ onih koji putuju dulje od 45 minuta misle da im duljina putovanja utječe na školski uspjeh. Među onima koji putuju dulje od 30 minuta takvih je 24,1\%. Spuštajući se na razinu obrazovanoga profila, kod gimnazijalaca su redom udjeli iznosili 16,2 \% (1), 16,2 \% (2), 9,3\% (3), 7,0 $\%$ (4) te $51,1 \%$ (5), kod učenika trogodišnjih strukovnih usmjerenja 55,0 \% (1), 15,2 \% (2), 8,5 \% (3), 5,1 \% (4) te $7,6 \%$ (5), a kod četverogodišnjih strukovnih usmjerenja $24,3 \%(1), 23 \%(2), 35,1 \%(3), 12,2 \%$ (4) te $5 \%(5)$.

$\mathrm{Na}$ pitanje da ocijene javnoprijevozničke usluge (na ljestvici od 1 do 5) prosječna ocjena javnoprijevozničke usluge iznosila je 3,61.

Osim anonimnog anketnog ispitivanja za potrebe istraživanja vođena su i dva dnevnika putovanja. Dnevnik putovanja vodila je ispitanica učenica putnica iz naselja Viljevo čija topološka udaljenost od Donjega Miholjca iznosi $9,5 \mathrm{~km}$. Učenica stanuje oko $200 \mathrm{~m}$ od autobusne stanice s koje svakodnevno odlazi u školu autobusom. S obzirom na uvriježene parametre dostupnosti stanica javnoga autobusnog prijevoza od $400 \mathrm{~m}$ ispitanica mjestom stanovanja nije ušla u skupinu prometno marginaliziranih osoba. U razdoblju od 4. do 8. travnja 2016., kad je bila u jutarnjoj smjeni, te u razdoblju od 11 . do 15. travnja 2016. godine, kad je bila u popodnevnoj smjeni u školi, svakodnevno je vodila dnevnik putovanja s točnim vremenom početka i završetka svake kretnje prema putu u školu i prema putu iz škole doma. Isto je činio i ispitanik stacionirani učenik koji živi oko $700 \mathrm{~m}$ zračne linije od škole. Ispitanici pohađaju isti razred, s istim rasporedom sati. Rezultati su prikazani u tablicama od 4 do 7 .

Učenica putnica u intervju je izjavila da putovanje autobusom predugo traje : ...u usporedbi dva-tri puta dulje jer ne idemo direktno prema Miholjcu, već skupljamo ostale po okolnim selima. Također, istaknula je da joj je glavni problem u jutarnjoj smjeni to što spava puno manje nego ostali učenici u razredu jer zbog dolaska okolnim putem moraju kretati ranije, dok u popodnevnoj 
Tab. 4 Travel diary of female travelling pupil for April $6^{\text {th }}, 2016$

Tab. 4. Dnevnik putovanja učenice-putnice na dan 6. travnja 2016.

\begin{tabular}{|c|c|c|}
\hline $\begin{array}{l}\text { Time (h:min) } \\
\text { / Vrijeme (h:min) }\end{array}$ & Event / Događaj & $\begin{array}{c}\text { Duration } \\
\text { /Vremensko trajanje }\end{array}$ \\
\hline $6: 12$ & $\begin{array}{l}\text { Leaving house } \\
\text { / Izlazak iz kuće }\end{array}$ & \multirow{5}{*}{$\begin{array}{l}46 \text { minutes } \\
\text { / } 46 \text { minuta }\end{array}$} \\
\hline $6: 16$ & $\begin{array}{l}\text { Arrival at bus stop in Viljevo } \\
\text { / Dolazak na autobusnu stanicu u Viljevu }\end{array}$ & \\
\hline $6: 23$ & $\begin{array}{l}\text { Bus arrival, entering bus, and departure for Donji Miholjac } \\
\text { / Dolazak autobusa i ulaz u autobus, polazak za Donji Miholjac }\end{array}$ & \\
\hline $6: 47$ & $\begin{array}{l}\text { Arrival at bus station in Donji Miholjac } \\
\text { / Dolazak na autobusnu stanicu u Donjem Miholjcu }\end{array}$ & \\
\hline $6: 58$ & $\begin{array}{l}\text { Arrival to school } \\
\text { / Dolazak u školu }\end{array}$ & \\
\hline $7: 00$ & $\begin{array}{l}\text { Beginning of classes } \\
\text { / Početak nastave }\end{array}$ & \\
\hline $13: 00$ & $\begin{array}{l}\text { End of classes and exiting school } \\
\text { / Završetak nastave i izlazak iz škole }\end{array}$ & \multirow{5}{*}{$\begin{array}{l}32 \text { minutes } \\
\text { / } 32 \text { minuta }\end{array}$} \\
\hline $13: 03$ & $\begin{array}{l}\text { Arrival at bus station in Donji Miholjac } \\
\text { / Dolazak na stanicu u Donjem Miholjcu }\end{array}$ & \\
\hline $13: 05$ & $\begin{array}{l}\text { Arrival of the bus and departure for Viljevo } \\
\text { / Dolazak na stanicu i početak putovanja za Viljevo }\end{array}$ & \\
\hline $13: 26$ & $\begin{array}{l}\text { Arrival at Viljevo } \\
\text { / Dolazak u Viljevo }\end{array}$ & \\
\hline $13: 32$ & $\begin{array}{l}\text { Return home } \\
\text { / Dolazak kući }\end{array}$ & \\
\hline
\end{tabular}

Impact of transportation connectivity on the academic achievement of secondary school pupils: case study of the Donji Miholjac Secondary School, Croatia

Utjecaj prometne povezanosti na školski uspjeh srednjoškolaca: primjer Srednje škole Donji

Miholjac, Hrvatska

Source: Respondent G.K. (18)

Izvor: Ispitanica G.K. (18)

in the afternoon week, the wait after arriving in Donji Miholjac until the start of class was too long. She particularly stressed the issue of sleep deprivation, claiming that her testing results were always poorer in the morning weeks than in the afternoon weeks.

In order to establish objective indicators of academic success, the school provided the academic success of pupils. The pupil averages, given the selected variables, are shown in Table 8. smjeni predugo čeka od dolaska u Donji Miholjac do početka nastave. Problem s manjkom sna posebno ističe te navodi kako su joj rezultati ispitivanja slabiji u jutarnjoj nego u popodnevnoj smjeni.

Kako bi se utvrdili objektivni pokazatelji školskoga uspjeha od škola su dobiveni podaci o školskom uspjehu učenika. Prosjeci učenika s obzirom na odabrane varijable prikazani su u Tab. 8 . 
HRVATSKI

GEOGRAFSKI

GLASNIK

79/2, 87-108 (2017.)

Tab. 5 Travel diary of female travelling pupil for April $13^{\text {th }}, 2016$

Tab. 5. Dnevnik putovanja učenice-putnice na dan 13. travnja 2016.

\begin{tabular}{|c|c|c|}
\hline $\begin{array}{l}\text { Time (h:min) } \\
\text { /Vrijeme (h:min) }\end{array}$ & Event / Događaj & $\begin{array}{c}\text { Duration } \\
\text { / Vremensko trajanje }\end{array}$ \\
\hline $11: 45$ & Leaving house / Izlazak iz kuće & \multirow{5}{*}{$\begin{array}{l}41 \text { minutes }+34 \\
\text { minutes waiting for } \\
\text { the beginning of the } \\
\text { classes } \\
\text { / } 41 \text { minuta }+34 \\
\text { minute čekanja } \\
\text { početka nastave }\end{array}$} \\
\hline 11:51 & Arrival at bus stop in Viljevo / Dolazak na autobusnu stanicu u Viljevu & \\
\hline 11:52 & $\begin{array}{l}\text { Bus arrival, entering bus, and departure for Donji Miholjac } \\
\text { / Dolazak autobusa i ulaz u autobus, polazak za Donji Miholjac }\end{array}$ & \\
\hline $12: 13$ & $\begin{array}{l}\text { Arrival at bus station in Donji Miholjac } \\
\text { / Dolazak na autobusnu stanicu u Donjem Miholjcu }\end{array}$ & \\
\hline $12: 26$ & Arrival to school / Dolazak u školu & \\
\hline 13:00 & Beginning of classes / Početak nastave & \\
\hline 19:00 & End of classes and exiting school / Završetak nastave i izlazak iz škole & \multirow{5}{*}{$\begin{array}{l}38 \text { minutes } \\
\text { / } 38 \text { minuta }\end{array}$} \\
\hline 19:04 & $\begin{array}{l}\text { Arrival at bus station in Donji Miholjac } \\
\text { / Dolazak na stanicu u Donjem Miholjcu }\end{array}$ & \\
\hline $19: 10$ & $\begin{array}{l}\text { Arrival of the bus and departure for Viljevo } \\
\text { / Dolazak na stanicu i početak putovanja za Viljevo }\end{array}$ & \\
\hline 19:32 & Arrival at Viljevo / Dolazak u Viljevo & \\
\hline $19: 38$ & Return home / Dolazak kući & \\
\hline
\end{tabular}

Source: Respondent G.K. (18)

Izvor: Ispitanica G.K. (18)

Tab. 6 Travel diary of male resident pupil for April $6^{\text {th }}, 2016$

Tab. 6. Dnevnik putovanja stacioniranog učenika na dan 6. travnja 2016.

\begin{tabular}{|c|c|c|}
\hline $\begin{array}{l}\text { Time (h:min) } \\
\text { / Vrijeme (h:min) }\end{array}$ & Event / Događaj & $\begin{array}{c}\text { Duration } \\
\text { / Vremensko trajanje }\end{array}$ \\
\hline $6: 51$ & Leaving house / Izlazak iz kuće & \multirow{3}{*}{$\begin{array}{l}9 \text { minutes } \\
\text { / } 9 \text { minuta }\end{array}$} \\
\hline $6: 59$ & Arrival to school / Dolazak u školu & \\
\hline $7: 00$ & Beginning of classes / Početak nastave & \\
\hline $13: 00$ & End of classes and exiting school / Završetak nastave i izlazak iz škole & \multirow{2}{*}{$\begin{array}{l}11 \text { minutes } \\
/ 11 \text { minuta }\end{array}$} \\
\hline $13: 11$ & Return home / Dolazak kući & \\
\hline
\end{tabular}

Source: Respondent I.P. (18)

Izvor: Ispitanica I.P. (18)

Tab. 7 Travel diary of male resident pupil for April 13th 2016

Tab. 7. Dnevnik putovanja stacioniranog učenika na dan 13. travnja 2016.

\begin{tabular}{|c|l|c|}
\hline $\begin{array}{c}\text { Time (h:min) } \\
\text { / Vrijeme (h:min) }\end{array}$ & \multicolumn{1}{|c|}{ Event / Događaj } & $\begin{array}{c}\text { Duration } \\
\text { /Vremensko trajanje }\end{array}$ \\
\hline 12:50 & Leaving house / Izlazak iz kuće & 10 minutes \\
\hline 12:57 & Arrival to school / Dolazak u školu & 10 minuta \\
\hline $13: 00$ & Beginning of classes / Početak nastave & 9 minutes \\
\hline $19: 00$ & End of classes and exiting school / Završetak nastave i izlazak iz škole & / 9 minuta \\
\hline 19:09 & Return home / Dolazak kući & \\
\hline
\end{tabular}

Source: Respondent I.P. (18)

Izvor: Ispitanica I.P. (18) 
Tab. 8 Average grades of pupils of Donji Miholjac Secondary School

Tab. 8. Prosjeci učenika Srednje škole „Donii Miholjac”

\begin{tabular}{|c|c|c|c|c|c|}
\hline $\begin{array}{c}\text { Grade } \\
\text { / Razred }\end{array}$ & Profile / Profil & $\begin{array}{c}\text { Average } \\
\text { grade (total) } \\
\text { / Prosjek } \\
\text { (uk.) }\end{array}$ & $\begin{array}{l}\text { Average } \\
\text { grade } \\
\text { (traveling } \\
\text { pupils) } \\
\text { / Prosjek } \\
\text { (učenici - } \\
\text { putnici) }\end{array}$ & 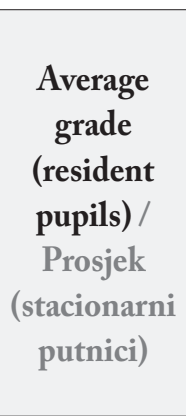 & $\begin{array}{c}\text { Difference } \\
\text { (travelling } \\
\text { pupils - } \\
\text { resident } \\
\text { pupils) } \\
\text { / Razlika } \\
\text { izmedu } \\
\text { prosjeka UP } \\
\text { i SU }\end{array}$ \\
\hline 1. & $\begin{array}{c}\text { Three-year programme } \\
\text { / Trogodišnji }\end{array}$ & 100 & 100.13 & 99.36 & 0.77 \\
\hline 2. & $\begin{array}{c}\text { Three-year programme } \\
\text { / Trogodišnji }\end{array}$ & 100 & 99.47 & 104.58 & -5.11 \\
\hline 3. & $\begin{array}{c}\text { Three-year programme } \\
\text { / Trogodišnji }\end{array}$ & 100 & 98.48 & 107.93 & -9.45 \\
\hline 1. & $\begin{array}{c}\text { Four-year programme } \\
\text { / Četverogodišnji }\end{array}$ & 100 & 99.37 & 101.59 & -2.22 \\
\hline 2. & $\begin{array}{c}\text { Four-year programme } \\
\text { / Četverogodišnji }\end{array}$ & 100 & 101.58 & 96.54 & 5.04 \\
\hline 3. & $\begin{array}{l}\text { Four-year programm } \\
\text { / Četverogodišnji }\end{array}$ & 100 & 98.92 & 101.4 & -2.08 \\
\hline 4. & $\begin{array}{l}\text { Four-year programme } \\
\text { / Četverogodišnji }\end{array}$ & 100 & 94.33 & 107.22 & -12.89 \\
\hline 1. & $\begin{array}{l}\text { Gymnasium } \\
\text { / Gimnazija }\end{array}$ & 100 & 93.75 & 108.15 & -14.4 \\
\hline 2. & $\begin{array}{l}\text { Gymnasium } \\
\text { / Gimnazija }\end{array}$ & 100 & 96.55 & 101.48 & -4.93 \\
\hline 3. & $\begin{array}{l}\text { Gymnasium } \\
\text { / Gimnazija }\end{array}$ & 100 & 96.44 & 103.13 & -6.69 \\
\hline 4. & $\begin{array}{c}\text { Gymnasium } \\
\text { / Gimnazija }\end{array}$ & 100 & 98.35 & 107.09 & -9.55 \\
\hline & $\begin{array}{c}\text { Three-year programme } \\
\text { / Trogodišnja škola }\end{array}$ & 100 & 99.36 & 103.96 & -4.6 \\
\hline & $\begin{array}{l}\text { Four-year programme } \\
\text { / Četverogodišnja škola }\end{array}$ & 100 & 98.55 & 101.69 & -3.14 \\
\hline & $\begin{array}{l}\text { Gymnasium } \\
\text { / Gimnazija }\end{array}$ & 100 & 96.27 & 104.96 & -8.69 \\
\hline
\end{tabular}

Impact of transportation connectivity on the academic achievement of secondary school pupils: case study of the Donji Miholjac Secondary School, Croatia

Utjecaj prometne povezanosti na školski uspjeh srednjoškolaca: primjer Srednje škole Donji

Miholjac, Hrvatska

Source: Survey (Pleić and Jakovčić, 2016) Izvor: Anketa (Pleić i Jakovčić, 2016) 


\section{Discussion}

Means of transport, transport connectivity, and the alignment of the bus schedule with the school's timetable

Young people are among the most frequent users of public transport, and it is necessary to ensure an efficient public transport system that will ensure their safety and comfort, so that they do not have to rely on their parents for longer and shorter journeys (Stafford et al., 2003). Of those surveyed, 99.1\% travelled to Donji Miholjac by bus (public transport). There were several factors that influenced the selection of the bus as the main means of transport: most of the pupils surveyed (74.1\%) were under the age of 18 years - the legal driving age in Croatia. Furthermore, the Ministry of Science, Education and Sport (as it was called at time of survey, now it is called Ministry of Education and Science), co-financed $75 \%$ of the monthly public transit pass for travelling pupils, while the remainder was covered by the Osijek-Baranja County or local government.

The average duration of bus ride to the school is 23 minutes, however, it should also be taken into account that $9.9 \%$ of travelling pupils travel less than 10 minutes to school, while $6.3 \%$ travel over 45 minutes. A weak association was found between the duration of travel and the subjective perception of the duration of travel $(r=-0.24)$, indicating that some pupils travelling up to 30 minutes to school considered the trip too long. One reason can be seen in the statement of the female pupil who kept the travel diary, stating that in comparison to travelling by car, the bus trip took 2 to 3 times longer, as the route was not direct, but instead picked up and dropped off pupils from other surrounding settlements. The bus companies plan their routes in order to maximise bus capacity per trip and make sure that as many pupils in the area as possible have access to public transportation, making the travel time longer. Such planned routes directly act to combat transport marginalisation, which can potentially lead to social exclusion of pupils (Gašparović, 2016; 2014b; Gašparović and Jakovčić, 2014).

The travel diaries kept by the two pupils explicitly showed a difference in the time spent travel-

\section{Rasprava}

Prijevozno sredstvo, prometna povezanost $i$ uskladenost rasporeda sati $i$ voznoga reda

Mladi su jedni od najčešćih korisnika javnoga prijevoza, stoga treba osigurati takav javni prijevoz koji će omogućiti sigurnost, udobnost te mogućnost korištenja bez potrebe oslanjanja na roditelje za putovanja na kraće i dulje udaljenosti (Stafford i dr., 2003). Čak se 99,1 \% ispitanika za dolazak u školu i povratak kući koristi javnim prijevozom. Kao objašnjenje ovakva rezultata mogu se navesti sljedeći čimbenici koji utječu na odabir autobusa kao primarnoga prijevoznoga sredstva: većina ispitanih, njih 74,1\%, ispod je dobne granice od 18 godina koja u hrvatskom zakonodavstvu dopušta posjedovanje vozačke dozvole za upravljanje osobnim vozilima. Nadalje, nadležno Ministarstvo znanosti, obrazovanja i sporta (u trenutku provođenja istraživanja, danas Ministarstvo obrazovanja i znanosti) sufinancira $75 \%$ cijene mjesečne karte javnoga prijevoza učenicima putnicima, dok preostali iznos pokriva Osječko-baranjska županija, odnosno lokalna samouprava, čime roditelji ne moraju podmirivati troškove prijevoza djece niti ih sami prevoziti.

Prosječno trajanje putovanja od mjesta prebivanja do mjesta školovanja je 23 minute, međutim $\mathrm{u}$ interpretaciji treba uzeti u obzir da se 9,9\% učenika putnika do škole vozi do 10 minuta, a 6,3 $\%$ više od 45 minuta. Uočena je i slaba povezanost između vremena trajanja putovanja i subjektivnoga doživljaja trajanja prometa $(r=-0,24)$. Pojedini ispitanici koji se voze do škole do 30 minuta trajanje putovanja doživljavaju predugim. Jedan od razloga iščitava se iz izjava ispitanice koja je vodila dnevnik putovanja kako u usporedbi s vožnjom automobilom putovanje traje i do 2-3 dulje jer autobus ne vozi izravno u Donji Miholjac, već prevozi i učenike iz okolnih mjesta, odnosno autoprijevoznici planiraju rute kako bi u jednoj vožnji iskoristili kapacitet autobusa te prevezli učenike putnike prema kojima planiraju svoje pravce putovanja, a što putovanje čini duljim. Takvim planiranjem pravaca izravno se djeluje na suzbijanju prometne marginalizacije koja potencijalno može dovesti do socijalne isključenosti učenika (Gašparović, 2016; 2014b; Gašparović i Jakovčić, 2014). 
ling to and from school. The travelling pupil spent an average of 75 minutes a day in travel in the morning week of school, and 110 minutes a day in the afternoon shift, as opposed to the resident pupil who spent an average of 20 minutes in travel time, in both shifts. This leads to the conclusion that the resident pupil is always in a more beneficial position, leaving more time for other activities - studying, extracurricular activities, etc. (Kalajdžić et al., 2015).

Wait time is a common benchmark for the efficiency of a transport system. In this study, wait time was viewed through the prism of the alignment of the school's timetable with the bus schedule, i.e. as the waiting time between the arrival of the bus to the school and the start of classes, or between the end of school and the departure of the bus. More than $50 \%$ of those surveyed waited up to 10 minutes before class, while $14 \%$ of those surveyed waited more than 45 minutes. Due to such extremes, the bus schedule and arrival at school could only be assessed to be somewhat aligned to the school's timetable, highlighting the need for greater awareness on the part of bus companies for pupils' needs, since the time spent travelling (or total travel duration) is the sum of the time spent travelling and the time spent waiting. On the other hand, the time spent waiting between the end of class and the departure of the bus was much more favourable, with $82.4 \%$ of pupils waiting a maximum of 20 minutes for a ride home, $67.9 \%$ a maximum of 10 minutes, and $3.6 \%$ of pupils waiting more than 45 minutes for the bus to leave. Only a little over $50 \%$ of pupils expressed their strong or partial agreement with the statement that the bus schedule is aligned with the school timetable, indicating the need to introduce adjustments to the bus schedule. The public transport service was mostly assessed to be very good or excellent (56.9\%), however, $43.1 \%$ of pupils assessed the service as insufficient, sufficient or good, showing there is substantial room for improvement. Besides time table, additional problems stated were old vehicles, poor quality of buses, behaviour of drivers and staff, and poor quality of service in general.
Iz dnevnika putovanja dvoje učenika eksplicitno je uočljiva razlika utrošenoga vremena za dolazak u školu odnosno odlazak iz škole učenika putnika i stacioniranoga učenika, pri čemu treba istaknuti da učenica putnica na putovanje dnevno utroši prosječno 75 minuta u dopodnevnoj, odnosno 110 minuta $u$ popodnevnoj smjeni, dok stacionirani učenik u dopodnevnoj i popodnevnoj smjeni prosječno potroši 20 minuta. Takav omjer dovodi do zaključka da je stacionirani učenik u povlaštenijem položaju, odnosno da mu ostaje više vremena za ostale aktivnosti - učenje, izvannastavne i izvanškolske aktivnosti pa i odmor (Kalajdžić i dr., 2015).

Vrijeme čekanja česta je mjera učinkovistosti prometnoga sustava. U ovom istraživanju vrijeme čekanja promatra se kroz prizmu usklađenosti rasporeda sati i voznoga reda, tj. kao vrijeme čekanja između dolaska autobusa u mjesto školovanja i početka prvoga sata, odnosno između kraja zadnjega sata i odlaska autobusa iz mjesta školovanja. Preko $50 \%$ ispitanih čeka do 10 minuta početak nastave, dok $14 \%$ ispitanih čeka više od 45 minuta. Zbog takvih krajnosti vozni red prilikom dolasku u školu može se ocijeniti uvjetno usklađenim s rasporedom sati, uz potrebu veće senzibilizacije autoprijevoznika za učeničke potrebe s obzirom na to da je utrošak vremena (ili ukupno trajanje vremena putovanja) jednak zbroju vremena trajanja putovanja i čekanja. S druge strane, vrijeme čekanja između završetka nastave i odlaska autobusa puno je povoljnije raspoređeno za učenike tako da $82,4 \%$ učenika čeka najviše 20 minuta na prijevoz kući, odnosno 67,9 \% najviše 10 minuta, a više od 45 minuta čeka njih 3,6 \%. Tek nešto više od $50 \%$ učenika izrazilo je potpuno ili djelomično slaganje s tvrdnjom da je vozni red usklađen s rasporedom sati, što svakako upućuje na nezadovoljstvo te moguću potrebu za modifikacijom voznoga reda. Uslugu javnoga prijevoza najčešće ocjenjuju ocjenama vrlo dobar i izvrstan $(56,9 \%)$, međutim $43,1 \%$ ocjena nedovoljan, dovoljan i dobar pokazuju da ipak postoji potreba za poboljšanjem usluge. Uz vozni red zaseban je problem starost voznoga parka, kvaliteta autobusa, ljubaznost vozača i općenito loša kvaliteta usluge.
T. Pleić

M. Jakovčić

Impact of transportation connectivity on the academic achievement of secondary school pupils: case study of the Donji Miholjac Secondary School, Croatia

Utjecaj prometne povezanosti na školski uspjeh srednjoškolaca: primjer Srednje škole Donji

Miholjac, Hrvatska 


\section{Academic success and pupil travel habits}

With regard to academic success, this most often implies the pupils (numerical) grade, as numerical indicators of the pupil's knowledge. However, academic success is not simply a reflection of knowledge - it is also a reflection of various factors that leave direct and indirect consequences on a pupil's academic success (Macuka and Burić, 2015). Hattie (2009, as cited in Dević, 2015) listed 138 variables or predictors found to be associated with academic success. The subject of this study was the influence of transport connectivity, or daily travel habits, as a predictor of pupils' academic success, which is an unjustly neglected topic in the study of academic success.

As part of the anonymous survey, pupils were first asked to assess the impact of their daily travels on their academic success. Among them, $40.6 \%$ expressed disagreement, and $15.6 \%$ agreement with the claim that their daily travel reflects on their academic success. The differences between pupils were dependent on the length of their daily travels. For example, $42.8 \%$ of pupils who travelled longer than 45 minutes believed that this impacted their academic success. For pupils travelling between 30 and 45 minutes, that share was $24.1 \%$. On the other hand, $41.1 \%$ of pupils travelling less than 30 minutes believed that their travel time did not impact their grades, and $22.6 \%$ that it mostly did not impact their grades. However, when considering the objective indicator of grade averages obtained from the school, the results can be seen in a somewhat different light. Though travelling pupils achieved a higher grade average in two years of the three-year programmes (the $1^{\text {st }}$ and $2^{\text {nd }}$ years, respectively), the situation was the opposite for all other cases. The largest difference was found among the pupils from the gymnasium programme, in which $58.1 \%$ stated that their daily travel habits had an impact on their grades. They spend part of their day traveling, instead of using that time to study, which is particularly emphasised due to the frequently-stated issue of the difficulty of the gymnasium curriculum (Biondić-Ivanković et al., 2004). This was also confirmed in the interview with the travelling pupil who kept the travel diary, and who stressed problems with lack of sleep and fatigue due to the length of her travelling time. It also shows that the time spent in transport should be viewed from a broader perspective, as an indirect factor that affects all

\section{Školski uspjeh i cirkulacija učenika}

Govoreći o školskom uspjehu, nerijetko se misli samo na učeničke ocjene koje su brojčani pokazatelj znanja učenika. Međutim, školski uspjeh nije samo odraz znanja - on je odraz i različitih čimbenika koji na nj ostavljaju izravne i neizravne posljedice (Macuka i Burić, 2015). Tako Hattie (2009 prema Dević, 2015) izdvaja 138 varijabli ili prediktora koji su povezani sa školskim uspjehom. Predmet našega istraživanja bio je utjecaj prometne povezanosti ili svakodnevnoga putovanja na učenikov školski uspjeh, a što je nepravedno zanemarena činjenica kada se istražuje školski uspjeh.

U sklopu anonimnoga anketnog ispitivanja od ispitanika se prvo tražila procjena utjecaja svakodnevnoga putovanja na njihov školski uspjeh. Pritom je 40,6 \% ispitanih izrazilo neslaganje, a 15,6 $\%$ slaganje s tvrdnjom da svakodnevne cirkulacije imaju odraz na njihov školski uspjeh. Razlike među učenicima postoje ovisno o duljini putovanja. Tako primjerice $42,8 \%$ učenika čije putovanje traje dulje od 45 minuta smatra da im to utječe na školski uspjeh. Kod učenika koji putuju između 30 i 45 minuta taj udio iznosi $24,1 \%$. S druge pak strane, 41,07\% učenika koji putuju kraće od 30 minuta smatra da im duljina putovanja ne utječe na uspjeh, a daljnjih $22,56 \%$ da uglavnom ne utječe. Međutim, kad se u obzir uzmu objektivni pokazatelji prosjeka ocjena dobiveni u školi, rezultati su drugačiji. Iako u dvama godištima trogodišnjega usmjerenja (1. i 2. razredi trogodišnjega usmjerenja) učenici putnici u prosjeku postižu bolje školske uspjehe, u svim ostalim slučajevima situacija je obratna. Najveće razlike primjećuju se u gimnazijskim profilima, a koji su i sami, njih $58,1 \%$, izrazili slaganje s tvrdnjom da svakodnevno putovanje ima posljedice na njihov uspjeh. Umjesto da troše dio svojega vremena na putovanje, to bi vrijeme mogli iskoristiti za učenje s obzirom na to da se težina i opsežnost gimnazijskoga programa često ističe kao problem (Biondić-Ivanković i dr., 2004). Potvrđuje to i intervju s učenicom putnicom koja je vodila dnevnik putovanja i koja je kao probleme povezane s duljinom putovanja navela nedostatak sna i umor. Također, to pokazuje i da utrošak vremena provedenog u prijevozu treba promatrati iz širega aspekta, kao posredan utjecaj na ostale aspekte 
other aspects of the lives of travelling pupils. On the other hand, pupils in the three-year vocational schools (70.2\%) stated that they strongly or partially disagreed that daily travel habits and living in a place far away from their place of schooling had an effect on their academic success. However, the data suggest otherwise. For pupils in the three-year vocational programmes, the difference between the average academic success of travelling pupils throughout the entire programme and the success of resident pupils was half the number found for gymnasium pupils. The most pupils in fouryear vocational programmes did not have an opinion (35.1\%), and, generally, the differences in academic successes between travelling and resident pupils was the smallest (regarding this group). However, when examined at the level of individual years, two extremes were evident. The first was the case in the $2^{\text {nd }}$ year of the four-year programme, where travelling pupils achieved higher academic success (by 5.2\%) than resident pupils, while the second case in the $4^{\text {th }}$ year of the same programme, where travelling pupils achieved lower success (by $12.0 \%$ ) than resident pupils. From this, it can be concluded that the gymnasium pupils were most realistic in the self-assessment of their success and the external factor of transport that impacted success, while travelling pupils of three-year vocational schools underestimated the impact of their daily travel habits on academic success. In comparing the total results of the self-assessment and actual school grades, there were evident differences in the subjective perception of success and actual success, in support of previous findings (Freeberg, 1988; Bahrick et al., 1996; Caldwell et al., 2002) that stated that pupils more often overestimated their academic success, rather than underestimating it or giving a realistic assessment. It is necessary to see the correlation between the responses pertaining to the duration of travel and responses on how travel habits affect academic success $(r=0.38)$, where there is an association between increasing agreement with the statement that travel to school takes too long and increasing agreement that the daily travel habits have an effect on academic success. This once again confirms that transport is one of the most crucial predictors of academic success. However, we are aware that transportation is just one of many geographical predictors, and that to gain a full sense of the scope of the problem, other predictors should be taken into account, such as socioeconomic situation, parents' education level, etc. života učenika putnika. S druge strane, učenici trogodišnjih strukovnih škola, njih 70,2 \%, izjavilo je da u potpunosti ili djelomično odbacuju tvrdnju kako svakodnevn cirkulacija i život u drugom mjestu od mjesta školovanja imaju utjecaja na njihov školski uspjeh. Međutim, konkretni podaci pokazuju suprotno. Ipak, kod učenika trogodišnjih strukovnih usmjerenja razlika između prosječnoga školskog uspjeha učenika putnika cjelokupnoga trogodišnjeg strukovnog usmjerenja i prosječnoga školskog uspjeha stacioniranih učenika istoga usmjerenja upola je manja od takve razlike kod gimnazijalaca. Najviše ispitanih koji pohađaju četverogodišnje strukovne škole nema definiran stav (35,1\%). Kad se ukupno gleda, razlike u školskom uspjehu su najmanje, međutim, kada se spusti na razinu godišta, uočavaju se dva ekstrema - prvi je slučaj u 2. razredu četverogodišnjih usmjerenja, gdje učenici putnici prosječno ostvaraju bolji školski uspjeh i to za 5,22 \%, dok je drugi u 4. razredu četverogodišnjih usmjerenja, gdje učenici putnici ostvaruju lošiji školski uspjeh od stacioniranih učenika i to za $12,02 \%$. Na osnovi tih podataka možemo tvrditi da su gimnazijalci najrealniji pri samoprocjeni svojega uspjeha i vanjskoga čimbenika prometa koji na njega utječe, dok učenici putnici trogodišnjih strukovnih škola podcjenjuju utjecaj svakodnevnih cirkulacija na školski uspjeh. Uspoređujući ukupne rezultate samoprocjene i školskih uspjeha u obliku prosječnih ocjena, vidljive su razlike u subjektivnom doživljaju uspjeha i stvarnoga uspjeha, čime se potvrđuju dosadašnje spoznaje (Freeberg, 1988; Bahrick i dr. 1996; Caldwell i dr., 2002) koje govore da učenici češće precjenjuju svoj školski uspjeh nego što ga podcjenjuju ili ocjenjuju realno. Valja uočiti i korelacijsku vezu između odgovora vezanih za duljinu trajanja putovanja i odgovora vezanih za utjecaj cirkulacije i školskog uspjeha $(r=0,38)$, gdje se uočava zakonitost da se pojačavanjem slaganja s tvrdnjom kako putovanje do škole traje predugo pojačava i slaganje s tvrdnjom da svakodnevna cirkulacija ima utjecaja na školski uspjeh, čime se ponovno potvrđuje da je promet jedan od važnih prediktora u obrazovanju učenika. Pritom smo svjesni činjenice da je promet samo jedan od geografskih prediktora, dok bi za dobivanje pune slike trebalo uzeti u obzir i neke druge prediktore poput socio-ekonomskoga statusa obitelji učenika, stupnja obrazovanja roditelja i slično.
T. Pleić M. Jakovčić

Impact of transportation connectivity on the academic achievement of secondary school pupils: case study of the Donji Miholjac Secondary School, Croatia

Utjecaj prometne povezanosti na školski uspjeh srednjoškolaca: primjer Srednje škole Donji

Miholjac, Hrvatska 


\section{Conclusions}

There is a wide range of available studies on predictors of academic success, however, the case of travelling pupils and how their daily travel habits affect their academic success has not yet been sufficiently addressed. Pupils are among the most common users of public transport services, travelling on a daily basis. This study was made upon the assumption that daily travel habits have a certain effect on their academic success, without neglecting other series of predictors.

On the basis of the data obtained by surveying travelling pupils and an analysis of their academic success, the research showed the following: travelling pupils, though they generally did not feel as though their daily travel habits had an effect on their academic success, on average achieved poorer academic results by the end of the school year, in comparison to resident pupils. This could be explained by the time spent every day in travel, which instead could be spent studying or resting, thereby confirming the hypothesis that transport connectivity is an objective predictor of academic success. However it is necessary to state that transportation is just one of many geographical predictors of academic success. Furthermore, the conducted analysis did not give us an answer regarding the level of impact that transportation has on academic success in comparison to other geographical factors. Additionally, legislation in Croatia regarding protection of personal data prevented us from further analysing the position of transportation in comparison to other predictors such as socioeconomic situation, level of income, etc.

Moreover, the study showed that according to the opinions of travelling pupils, the planned transport routes do not satisfy their needs, and that they should be redefined, in order to ensure that pupils are not subjected to transport marginalisation, which could lead to social exclusion. This can only be achieved through the mutual understanding of the needs of travelling pupils and the economic feasibility of those providing public transport services. In an equal opportunity society, transport connectivity is one of the segments of education

\section{Zaključak}

O prediktorima školskoga uspjeha dosad je napisan priličan broj znanstvenih radova, međutim, $\mathrm{u}$ tom je proučavanju izostavljen slučaj učenika putnika, odnosno kako njihove svakodnevne cirkulacije determiniraju školski uspjeh. Učenici putnici jedni su od najčeščih korisnika usluga javnoprijevozničkih usluga, oni svakodnevno putuju od mjesta prebivanja do mjesta školovanja i natrag. S pretpostavkom da takva svakodnevna cirkulacija u određenoj mjeri determinira njihov uspjeh, ne zanemarujući čitav niz ostalih prediktora, istraživanju te tematike pristupilo se na konkretnom primjeru učenika putnika Srednje škole Donji Miholjac.

$\mathrm{Na}$ temelju podataka dobivenih anketiranjem učenika putnika i analizom njihova školskoga uspjeha istraživanje je pokazalo sljedeće: učenici putnici, iako općenito ne osjećaju da svakodnevne cirkulacije utječu na njihov školski uspjeh, postižu prosječno slabije rezultate na kraju nastavne godine u usporedbi sa stacioniranim učenicima. Slabiji rezultati mogu se objasniti svakodnevnim vremenskim troškom koji bi se umjesto na putovanja mogao usmjeriti na učenje ili odmor, čime je istraživačka hipoteza prema kojoj je prometna povezanost objektivni prediktor školskoga uspjeha potvrđena. Naravno, uzimamo u obzir da je prometna povezanost samo jedan od geografskih prediktora školskoga uspjeha. Provedena analiza ne daje nam odgovor na pitanje koliki je utjecaj prometa među ostalim prediktorima povezanima s razlikama među stacionarnim učenicima i učenicima putnicima. Potreba zaštite osobnih podataka ne daje nam pak mogućnost za daljnju analizu i pozicioniranje prometa u odnosu na ostale prediktore poput socioekonomskoga statusa obitelji, visine prihoda i slično.

Također, istraživanje je pokazalo da učenici putnici planirane prometne rute ne smatraju odgovarajućima te da ih je potrebno redefinirati, pri čemu treba voditi računa da se ne pojavi prometna marginaliziranost, koja za posljedicu može imati socijalnu isključenost To se može postići jedino razumijevanjem potreba učenika putnika i imajući u vidu ekonomsku isplativost nositelja javnoprijevozničkih usluga. U društvu jednakih mogućnosti prometna povezanost kao jedan od segmenata obrazovanja, 
that has proven to be of exceptional importance, and travelling pupils should be provided services aimed at eliminating or minimising the differences between these pupils and resident pupils.

Finally, more studies of this type are needed to obtain a more complete overview of other important predictors of academic success, in order to deductively determine the impacts of transport connectivity on academic success. This paper gives guidelines for such future research. koji se pokazuje izrazito važnim, učenicima putnicima treba omogućiti takvu uslugu u kojoj se razlike između njih i stacioniranih učenika neće osjećati ili će biti svedene na minimum.

Konačno, istraživanja poput ovoga pridonose dobivanju potpunije slike važnosti utjecaja prometne povezanosti na školski uspjeh. Time ono daje polazne smjernice za daljnje proučavanje ovoga segmenta školovanja.
Alameda - Lawson, T., 2014: A Pilot Studiy of Collective Parent Engagement and Children's Academic Achievement, Children and Schools 36, 199-209.

Autor, D., Figlio, D., Karbownik, K., Roth, J., Wasserman, M., 2016: School Quality and the gender gap in educational achievement, American economic review: papers and procedings 106 (5), 289-295.

Axhausen, K.W., Zimmerman, A., Schönfelder, S., Rindsfüser, G., Haupt, T., 2003: Observing the rhytms of daily life: A six-week travel diary, Transportation 29 (2), 95-124.

Babarović, T., Burušić, J., Šakić, M., 2009: Uspješnost predviđanja obrazovnih postignuća učenika osnovnih škola Republike Hrvatske, Društvena istraživanja 18 (4-5), 673-695.

Babarović, T., Burušić, J., Šakić, M., 2010: Psihosocijalne i obrazovne odrednice školskog uspjeha učenika osnovnih škola: dosezi dosadašnjih istraživanja, Suvremena psibologija 13 (2), 235-256.

Bahrick, H. P., Hall, L. K., Berger, S. A., 1996: Accuracy and distortion in memory for high school grades, Psychological Science 7 (5), 265-271.

Biondić-Ivanković, P., Brlas, S., Matošević, Lj., Pofuk, Lj., Štetić, I., 2004: Zadovoljstvo učenika, roditelja i nastavnika školom u svjetlu rasterećenja učenika i nastavnog procesa u srednjoj školi, Život i škola 12 (2), 55-64.

Black, W.R., 2003: Transportation: a geographical analysis, The Guilford Press, New York.

Burušić, J., Šakić, M, Babarović,T., Dević, I., 2012: School achievement in urban and rural areas in Croatia: Is the quality of education equal for all?, in: Culture of educational policy: Comparative international issuses in policy-outcome relationship (ed: Boufoy-Bastick, B.), Strasbourg: Analytrics, 2-32.

Caldwell, C. H., Zimmerman, M. A., Bernat, D. H., Sellers, R. M., Notaro, P. C., 2002: Racial identity, maternal support, and psychological distress among African American adolescents, Child development 73 (4), 1322-1336.

Dautović, S., 1999: Emocionalni problemi djece i mladeži i školski uspjeh, Kriminalogija i socijalna integracija 7 (1), 105110.

Dević, I., 2015: Odrednice školskog postignuća učenika: provjera modela školske kompetencije (Doctoral dissertation), Filozofski fakultet Sveučilišta u Zagrebu, Zagreb.

Downey, D. B., 1995: When bigger is not better: Family size, parental resources, and children's educational performance, American Sociological Review 60 (5), 746-759.

Freeberg, N.E. (1988). Analysis of the Revised Student Descriptive Questionnaire, Phase I: Accuracy of Student Self-Reported Information. College Board Report No. 88-5, College Entrance Examination Bord, New York.

Friedman - Krauss, A.H., Raver C.C., 2015, Does school mobility plave elementary school children at risk for lower math achievement? The mediating role of cognitive dysregulation, Developmental Psychology 51 (12), 1725-1739.

Gašparović, S., 2014a: Utjecaj prometne marginaliziranosti na svakodnevni żivot srednjoškolske populacije Grada Zagre$b a$ (Doctoral dissertation), Geografski odsjek PMF-a Sveučilišta u Zagrebu, Zagreb.
Gašparović, S., 2014b: Impact of transport disadvantage on education of high school population of the City of Zagreb, in: Proceedings of the Second International Conference on Traffic and Transport Engineering ICTTE Belgrade 2014 (ed.: Cokorilo, O.), City Net Scientific Research Center, Beograd,789-800.

Gašparović, S., 2016: Theoretical postulates of transport disadvantage, Hrvatski geografski glasnik 78 (1), 73-95.

Gašparović, S. \& Jakovčić, M., 2014: Prometna marginaliziranost na primjeru srednjoškolaca Grada Zagreba, Geoadria 19 (1), 61-99.

Gregurović, M., Kuti, S., 2009: Učinak socioekonomskog statusa na obrazovno postignuće učenika: Primjer PISA istraživanja, Hrvatska 2006, Revija za socijalnu politiku 17 (2), 179-196.

Gyansah, S.T., Soku, R., Esilfie, G. (2015). Child Delinquency and Pupils' Academic Performance in Fumesua $\mathrm{Mu}-$ nicipal Assembly Primary School in the Ejisu-Juaben Municipality, Ashanti Region, Ghana, Journal of Education and Practice 6 (12), 107-120.

Halden, D., Jones, P., Wixley, S, 2005: Measuring Accessibility as Experiences by Different Socially Disadvantaged Groups, Working Paper 3: Accessibility Analysis Literature Review, Transport Studies Group, University of Westminster, London.

Hoyle, B. \& Knowles, R., 1998: Transport Geography: An Introduction, u: Modern Transport Geography, Second revised edition (eds.: Hoyle, B., Knowles, R.), John Wiley \& Sons, Chichester, 1-12.

Jamil, B. \& Khalid, R., 2016: Predictors of Academic Achievement in Primary school students, Pakistan Journal of Psy-
T. Pleić

M. Jakovčić

Impact of transportation connectivity on the academic achievement of secondary school pupils: case study of the Donji Miholjac Secondary School, Croatia

Utjecaj prometne povezanosti na školski uspjeh srednjoškolaca: primjer Srednje škole Donji

Miholjac, Hrvatska

\section{Literature}

Literatura 
HRVATSKI

GEOGRAFSKI

GLASNIK

79/2, 87-108 (2017.) chological Research 31 (1), 45-61.

Kalajdžić, O., Vuksanović, G., Rašević, Lj., Pavlović, A., Mastilo, B., Zečević, I., Ćalasan, S., Vuković, B. (2015), Socio-demografske determinante školskog uspjeha, Biomedicinska istraživanja 6 (2), 138-145.

Kamaruddin, R., Zainal, N. R., Aminuddin, Z. M., Kamaruzaman J., 2009: The Quality of Learning Environment and Academic Performance from a Student's Perception. International Journal of Business and Management 4 (4), 171-175.

Kramer, K. Z., 2012: Parental behavioural control and academic achievement: striking the balance between control and involvement. Research in Education $88,85-98$.

Kuterovac Jagodić, G., Keresteš, G., Brković, I., 2013: Osobni, obiteljski i okolinski prediktori školskog uspjeha: Provjera moderatorske uloge odrastanja u ratom različito pogođenim područjima Hrvatske, Psibologijske teme 22 (1), 1-28.

Maguin, E., Loeber, R., 1996: Academic performance and delinquency, in: Crime and justice: A review of research 20 (ed.: Tonry, M.), University of Chicago Press, Chicago, 154-264

Macuka, I., Burić, I., 2015: Školski uspjeh mlađih adolescenata: važnost uloge osobnih i obiteljskih čimbenika. Društvena istraživanja 24 (4), 487-507.

Maras, N., Rodek, J., 2012: Utjecaj nekih stratifikacijskih čimbenika na školski uspjeh. Školski vjesnik: časopis za ped- agoška i školska pitanja 61 (1-2), 41-57.

Masten, A. S., Roisman, G. I., Long, J. D., Burt, K. B., Obradović, J., Riley, J. R., Boelcke-Stennes, K., Tellegen, A., 2005: Developmental cascades: Linking academic achievement and externalizing and internalizing symptoms over 20 years. Developmental Psychology 41 (5), 733-746.

Moser C.A. \& Kalton, G., 1979: Survey Methods in Social Investigation $2^{\text {nd }} E d n$. Heinemann Educational Books, London.

Nelson J.R., Benner G.J., Lane K., Smith B.W., 2004: An investigation of the academic achievement of $\mathrm{K}-12$ students with emotional and behavioral disorders in public school settings, Exceptional children, 71, 59-74.

Owoeye, J. S. \& Yara, P. O., 2011: School location and academic performance of secondary school in Ekiti State, Nigeria, Asian School Science 7 (5), 170-175.

Păişi Lăzărescu, M., 2014: Psychological Factors of Academic Success, in: The 6th International Conference Edu World 2014 "Education Facing Contemporary World Issues", 7th - 9th November 2014, Procedia - Social and Behavioral Sciences, 1632-1637.

Raychaudhuri, A., Debnath, M., Sen, S., Majumder, B.G., 2010: Factors affecting Student's academic performance: A case study in Agartala Municipal Concial Area. Bangladesh e-journal of sociology 7 (2), 34-41.
Richardson, A.J., Ampt, E.S., Meyburg, A.H., 1995: Suvery Methods for Transport Planning, Eucalyptus Press, Parkville.

Saw, G.K., 2016: Patterns and trend sin achievement gaps in Malaysian Secondary Schools (1999-2011): gender, ethnicity, and socioeconomic status, Educational Research for Policy and Practice 15 (1), 41-54.

Sremić, I., Rijavec, M., 2010, Povezanost percepcije majčinog i očevog roditeljskog ponašanja i školskog uspjeha kod učenika osnovne škole, Odgojne znanosti 12 (2), 347-360.

Stafford, A., Laybourn, A., Hill, M., 2003: ,Having a say: Children and Young People Talk about Consultation. Children $\Xi^{\circ}$ Society 17, 361-373.

Tang, S., Davis - Kean, P.E., 2015: The association of punitive parenting practice and adolescent achievement. Journal of family psychology 29 (6), 873-883.

Yesilyurt, E., Say, D., 2016: Factors Affecting Success of High School Student sin Turkey. Ege Academic Review 16 (3), 541-554.

Zhang, L., Chen, J. (eds.), 2013: Academic Achievement: predictors, learning strategies and influences of gender, Novinka, New York.

Zhijun, S., Zeyun, L., Baicai, S., 2016: Families, schools and children's school achievement: A study based on rural regions in China Gansu Province. Chinese Education E' Society 48, 464-482.
Authors Autori
Tvrtko Pleić

tpleic@ffzg.hr

student, IV. year Integrated undergraduate and graduate university study in history and geography, University of Zagreb, Faculty of Arts and Humanities, Department of History, Ivana Lučića 3,

10000 Zagreb, Croatia

\section{Martina Jakovčić mjakovci@geog.pmf.hr}

Associate Profesor, University of Zagreb, Faculty of Science, Department of Geography, Marulićev trg 19/I, 10000 Zagreb, Croatia 